\title{
Research of Mosses Accumulation Properties Used for Assessment of Regional and Local Atmospheric Pollution
}

\author{
Nadezhda K. Ryzhakova ${ }^{1}$, Natalya S. $\operatorname{Rogova}^{1}$, Alex L. Borisenko ${ }^{2}$ \\ ${ }^{1}$ Institute of Physics and Technology, Tomsk Polytechnic University, Tomsk, RF \\ ${ }^{2}$ Institute of Biology, Tomsk State University, Tomsk, RF
}

cross $^{\text {ref }}$ http://dx.doi.org/10.5755/j01.erem.69.3.5566

(Received in October, 2014; accepted in September, 2014)

\begin{abstract}
The monitoring of atmospheric heavy metal and other toxic element depositions by using widespread bryophytes as biomonitors has been widely used. Choosing most appropriate moss species in relation to their accumulation properties is the main goal of this research. The accumulation of heavy metals and other toxic elements by widespread mosses of midland have been studied. The research is focused on assessing accumulation properties of 4 species of terrestrial moss, 4 species of paludal moss and 2 species of epiphytic moss. The concentrations of 32 elements have been determined in moss samples by neutron activation analysis (NAA) and atom emission spectrometry (AES). Interspecies and intraspecies comparison revealed significant differences in accumulation properties. The accumulation capacity of Dicranum polysetum was higher than other terrestrial mosses and Aulacomnium palustre had higher accumulation capacity than other paludal mosses. These moss species have been used for monitoring atmospheric pollutants in an immense territory, particularly for research of transboundary transfer of heavy metal pollution. The accumulation property of epiphytic moss was higher than others. The epiphytic moss could be found on the bark of old trees (aspens, poplars, birch) that are of frequent occurrence in urban areas. Therefore, epiphytic moss can be used for monitoring atmospheric pollutants in an immense territory and for research of atmospheric pollution in industrial centers, inhabited locations as well as assessment of atmospheric contamination in local pollution source.
\end{abstract}

Keywords: moss bioindicator, accumulation properties, NAA, AES, statistic methods

\section{Introduction}

Mosses concentrate a great number of heavy metals and the other trace elements from the air and precipitation in a very effective way (Coskun et al. 2011), (Grgie and Nadezdin 1990), (Onianwa 2001). They have no contact with the soil and consequently, the heterogeneous chemical composition does not practically affect them.

The morphological and physiological properties of mosses along with their widespread occurrence make them very useful to estimate surface air pollution by heavy metals (TM) and other trace elements (Burton and Agneta 1990), (Rühling 1994), (Steinnes 1989), (Steinnes et al. 1992). In conducting this type of research the main question is choosing the most suitable species of mosses based on their accumulation properties. For example, the ground species of moss (terrestrial, paludal) is used to study the transboundary transfer of atmospheric deposition of TM because they can be found in woodlands (Nikodemus et al. 2004), (Gerdol et al. 2000), (Chakrabortty and Paratkar 2006). Atmospheric pollution in urban areas can be analysed using epiphytic mosses. Epiphyte has long life cycle and grows on bark of old trees such as aspens, poplars and birches. It should be noted that the study (Chen et al. 2010), (Migaszewski et al. 2009), (Shotbolt et al. 2007) was focused on research of accumulation capacity of mosses in one systematic group terrestrial mosses.

The purpose of this research is analysis and comparison of widespread mosses of midland: 4 species of terrestrial moss (Pleurozium schreberi (Brid.) Mitt., Dicranum polysetum Sw., Ptilium cristacastrensis (Hedw.) De Not., Hylocomium splendens 
(Hedw.) B.S.G.), 4 species of paludal moss (Aulacomnium palustre (Brid.) Mitt., Sphagnum angustifolium (Russ. Es Russ.) C. Jens., Sphagnum squarrosum, Sphagnum centrale C. Jens. Ex H. Arnell et C. Jens.) and 2 species of epiphytic moss (Pylaisia polyantha (Hedw.) B.S.G., Orthotrichum obtusifolium Brid.).

\section{Materials and methods}

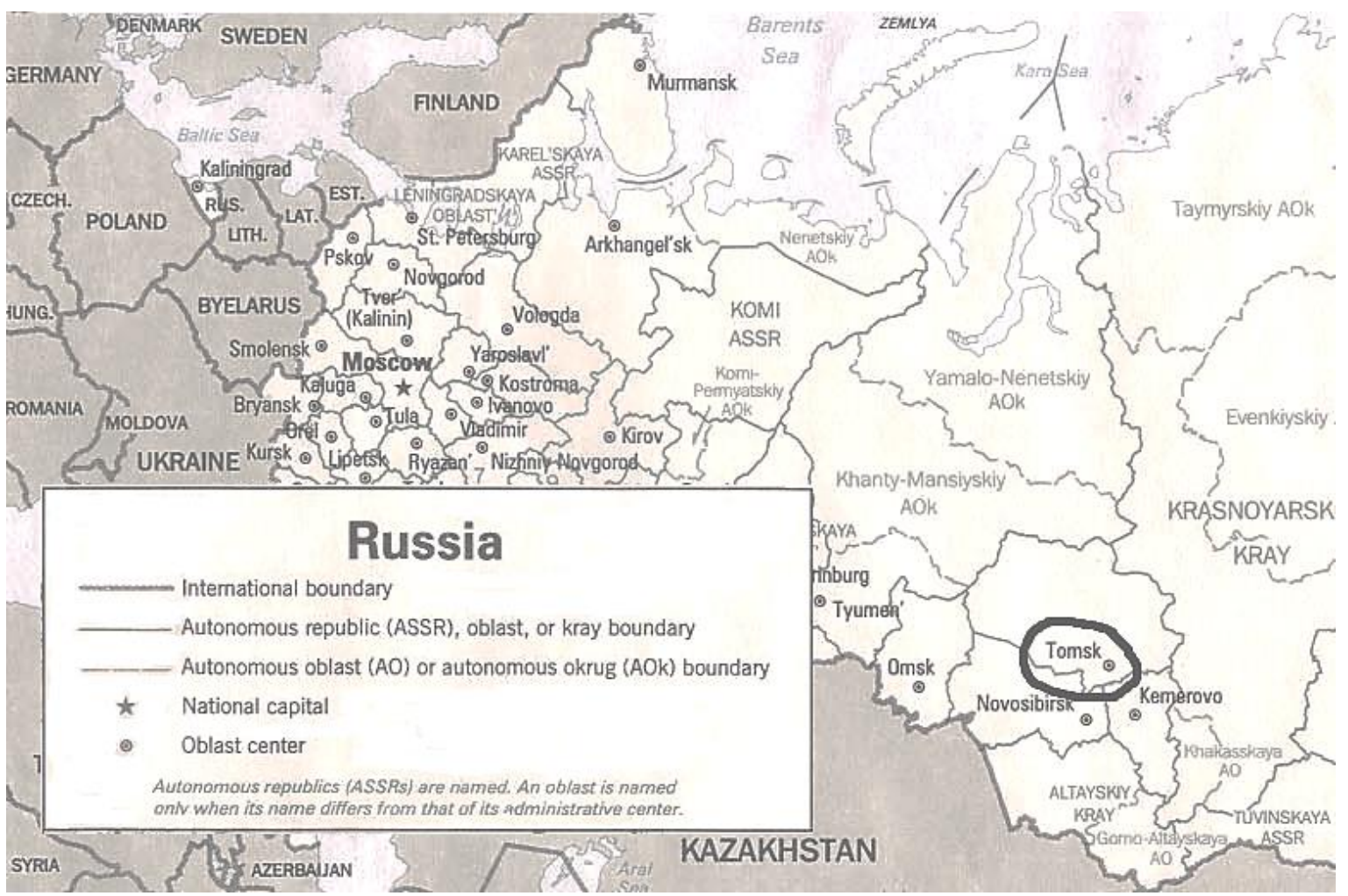

Fig. 1. The map of Russia, (black circle) territory of sampling mosses

\subsection{Study area}

The study was carried out in the town of Seversk, which is situated $56^{\circ} 26^{\prime} \mathrm{N}, 84^{\circ} 51^{\prime} \mathrm{E}, 75-90$ $\mathrm{m}$ above the sea level. The town is located $15 \mathrm{~km}$ northwest of Tomsk (Russia) (fig. 1) on the right bank terrace above flood-plain of the Tom River (fig. 2), southeast of West Siberian Plain. Population of the town is more than 100000 inhabitants. The prevailing wind direction is south and southwest. The climate is continental with warm summers and cold winters. Snow is frequent (snowing almost $50 \%$ of winter days. The difference between the record high and the record low temperatures is $95^{\circ}$. The rainfall distribution is intermittent (average annual precipitation is $570 \mathrm{~mm}$ ).

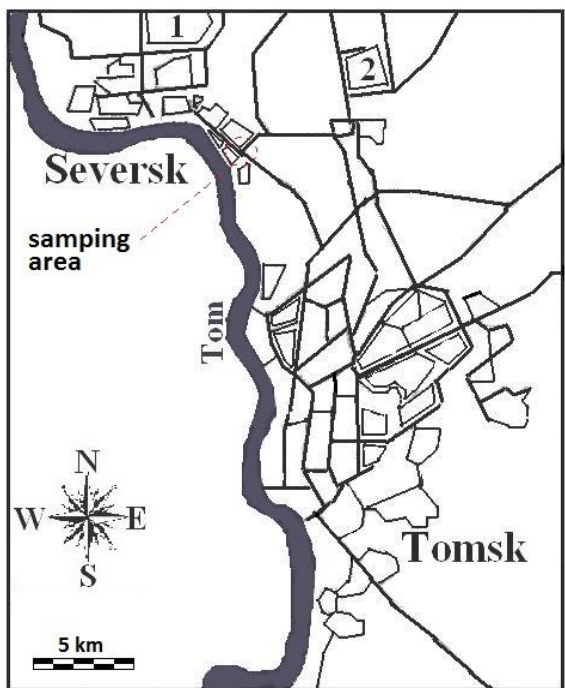

Fig. 2. The location of the sampling areas (1-Siberian Integrated Chemical Plant, 2-Tomsk Petrochemical Plant) 


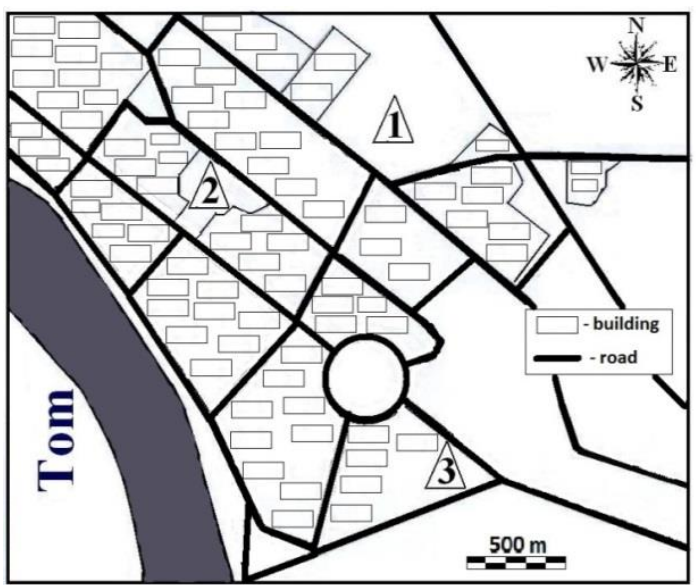

Fig. 3. Sampling areas and sites (1-terrestrial mosses, 2-paludal mosses, 3-epiphytic mosses)

Seversk is the town of the Siberian Group of Chemical Enterprises founded in 1954. It comprises several nuclear reactors and chemical plants for separation/ enrichment/ reprocessing of uranium and plutonium. Following an agreement signed in March 2003 between Russia and the United States to shut down Russia's three remaining reactors for plutonium production, two reactors for plutonium production located in Seversk have now been shut down.

\subsection{Collection and preparation of samples}

Samples of the terrestrial mosses Pleurozium schreberi, Dicranum polysetum, Ptilium cristacastrensis, Hylocomium splendens have been collected in green moss-dwarf-shrub pine forest in an area of $1 \mathrm{~m}^{2}$ at least $80 \mathrm{~m}$ from roads (fig. 3 site 1). Samples of four paludal species Aulacomnium palustre, Sphagnum angustifolium, Sphagnum squarrosum, Sphagnum centrale have been collected on dwarf-shrub-sedge-sphagnum bog in a small hollow with an area $5 \mathrm{~m}^{2}$ at least $60 \mathrm{~m}$ from roads (fig.3 site 2). Samples of two epiphytic species Pylaisia polyantha, Orthotrichum obtusifolium have been taken from the bark of old poplars at the height of 1,5-2 $\mathrm{m}$ above soil within an area 8-10 $\mathrm{m}^{2}$ at least $50 \mathrm{~m}$ from roads. The sampling sites were located in the same habitat. Therefore, it can be assumed that they were exposed to the same local anthropogenic load. The moss samples were collected in dry weather conditions in August/September 2010. Sampling and sample handing was performed by using polythene gloves and paper bags. In the laboratory, the samples were carefully cleaned from dead material and litter attached. The green younger parts of the moss have been selected to make the analysis. The moss was washed with distilled water, dried to a fixed weight in a special chamber at the temperature of $85^{\circ} \mathrm{C}$ during 24 hours before the analysis.

To estimate accumulative properties of mosses in relation to different chemical elements, a singlefactor analysis of variance has been performed for each group of terrestrial and paludal mosses (Steel and Torrie 1980). The method of series distribution comparison over dispersions and average values for epiphytic mosses was carried out.

\subsection{Measure of samples}

The content of elements in the moss samples was determined by neutron activation analysis and atom emission spectrometry. Each sample was separated into 10 parallel sub-samples for statistical analysis. 32 elements in each sample have been determined by NAA and AES.

Determination of eight elements by atom emission spectrometry (AES) with inductively coupled plasma iCAP6300 DUO was carried out at Research and Analytic Centre, Tomsk Polytechnic University, Tomsk, Russia. For AES, about $0.1 \mathrm{~g}$ of dry mass was digested in $1 \mathrm{ml}$ of $\mathrm{H}_{2} \mathrm{SO}_{4}$ during 30 min. The mixture of $4 \mathrm{ml}$ of $\mathrm{HNO}_{3}$ was heated at $200^{\circ} \mathrm{C}$ during $40 \mathrm{~min}$ and cooled at room temperature. The resulting solution was diluted with deionized water to $50 \mathrm{ml}$ and reference material was added.

The neutron activation analysis was carried out at the Tomsk Research Institute, Tomsk, Russia. For NAA, the moss samples were crumbled and the probes having the mass of $0.3 \mathrm{~g}$ and $1 \mathrm{~cm}$ in diameter were pressed and packed either into aluminum foil for their long-term irradiation. Samples have been irradiated in IRT-T reactor channels (thermal neutron flux density of $5.5 \times 10^{13} \mathrm{n} \mathrm{cm}^{-2} \mathrm{~s}^{-1}$ ). To determine elements yielding long-lived isotopes, reference materials have been packed together with 20-25 samples in a container and were irradiated for 5 hours. Then reference materials and samples were re-packed and measurements have been made thrice after 7,30 and 60 days of decay. The duration of measurements was 10,20 and $30 \mathrm{~min}$, respectively. The measurement of the chemical element specific activities in the probes was made by the semiconductor gamma spectrometer. The gamma spectra of induced activity were analyzed by means of "Genia-2000" software program developed by the "CONBERRA".

To ensure quality control, contents of elements yielding long-living isotopes have been determined using certified reference materials: INCT-OBTL-5 
(Institute of Nuclear Chemistry and Technology Oriental Basma Tobacco Leaves) and IAEA/V-10 Hay (International Atomic Energy Agency).

\section{Results and discussion}

The concentrations of chemical elements for each moss species are normally distributed. The single-factor analysis is tested by comparing the F test statistic:

$$
F=\frac{\sigma_{F}^{2}}{\sigma_{0}^{2}},
$$

Where: $\sigma_{F}^{2}=\frac{\sum_{i=1}^{r}\left(\bar{x}_{i}-\bar{x}\right)^{2}}{r-1}$ and

$$
\sigma_{0}^{2}=\frac{\sum_{i=1}^{r} \sum_{j=1}^{n_{i}}\left(x_{j}-\bar{x}_{i}\right)^{2}}{n-r}-\text { are intergroup and intragroup }
$$

dispersions accordingly figured out upon one degree of freedom.

Where: $\bar{x}$-overall mean, $\bar{x}_{i}$ - group average, $n_{i}$ - number of tests in group, $n$ - total number of tests, $r$-a number of groups. This F-statistic follows the Fdistribution with $\mathrm{r}-1, \mathrm{n}-r$ degrees of freedom under the null hypothesis.
The calculated F-ratios significantly exceed the critical values $\left(\mathrm{F}_{\mathrm{cr}}=2.8\right.$ for elements determined by NAA; $F_{c r}=3.09$ for elements determined by AES, the probability is equal to 0.95 (Steel and Torrie 1980) for all chemical elements. This goes to prove different accumulation capacity of both terrestrial and paludal moss species. Hence, in the course of the only investigation, the use of various terrestrial mosses collected from one area is incorrect.

The comparison of average values of concentrations for epiphitic mosses with a t-test has been carried out for the elements whose ratio of variances does not exceed the critical value. The analysis showed that only 3 elements $-\mathrm{Th}, \mathrm{Cs}, \mathrm{Co}-$ do not reveal any significant differences in the compared variances and average values. Thus, compared populations are heterogeneous, namely the differences of accumulation properties for various epiphytic moss species in most chemical elements.

To determine the extent of accumulation capacity, the average value concentrations of all chemical elements in an increasing order have been ranged (Manoukian 1986). Each concentration of a chemical element is assigned a rank. The number of ranks is equal to the amount of the moss species studied. In this instance, there are 10 ranks. The concentrations of $\mathrm{Mo}, \mathrm{Cr}, \mathrm{Zn}$ and corresponding concentration ranks are presented as an example in Table 1. The rank sums of all the chemical elements for each moss species have been calculated (Table 2).

Table 1. Concentration values for $\mathrm{Mo}, \mathrm{Cr}, \mathrm{Zn}$ in various mosses species $(\mathrm{mg} / \mathrm{kg})$ and their corresponding ranks

\begin{tabular}{||l|c|c|c|c|c|c||}
\hline \multirow{2}{*}{\multicolumn{1}{c|}{ Species of mosses }} & \multicolumn{2}{c|}{ Mo } & \multicolumn{2}{c||}{ Cr } & \multicolumn{2}{c||}{ Zn } \\
\cline { 2 - 7 } & value & rank & value & rank & value & rank \\
\hline Dicranum polysetum & 1.6 & 6 & 16 & 8 & 55 & 4 \\
\hline Aulacomnium palustre & 1.9 & 8 & 9.8 & 4 & 67 & 7 \\
\hline Ptilium crista-castrensis & 1.1 & 3 & 12 & 7 & 56 & 5 \\
\hline Sphagnum centrale & 0.45 & 2 & 11 & 5 & 46 & 2 \\
\hline Hylocomium splendens & 1.1 & 4 & 8.4 & 3 & 38 & 1 \\
\hline Sphagnum angustifolium & 1.7 & 7 & 8.1 & 1 & 56 & 6 \\
\hline Sphagnum squarrosum & 1.1 & 5 & 11 & 6 & 126 & 8 \\
\hline Pleurozium schreberi & 0.45 & 1 & 8.2 & 2 & 51 & 3 \\
\hline Pylasia polyantha & 72 & 10 & 92 & 10 & 307 & 9 \\
\hline Orthotrichum obtusifolium & 4.1 & 9 & 50 & 9 & 542 & 10 \\
\hline
\end{tabular}

The obtained data is well explained by the anatomical and morphological moss structure. For instance, the highest rank sum among terrestrial mosses was obtained for Dicranum polysetum, which has ample rhizoid felt and dense structure of bunches that probably forwards the retention of polluting components. Therefore, this species of moss has the highest accumulating capacity in comparison to other studied terrestrial mosses. Moss species Hylocomium splendens has the smallest rank sum, i.e. this moss species has the lowest accumulation capacity due to loose structure of its bunches and location of branches on the bine.

Table 2. Rank sums for the various terrestrial mosses

\begin{tabular}{|l|c|l|c||}
\hline \multicolumn{1}{|c|}{ Mosses species } & Rank sum & \multicolumn{1}{c|}{ Mosses species } & Rank sum \\
\hline Aulacomnium palustre & 108 & Ptilium crista-castrensis & 104 \\
\hline Sphagnum centrale & 57 & Hylocomium splendens & 62 \\
\hline Sphagnum angustifolium & 59 & Pleurozium schreberi & 75 \\
\hline Sphagnum squarrosum & 95 & Pylaisia polyantha & 173 \\
\hline Dicranum polysetum & 142 & Orthotrichum obtusifolium & 170 \\
\hline
\end{tabular}

Moss species Hylocomium splendens and Pleurozium schreberi used for monitoring in Europe (Berg and Steinnes 1997), (Culicov et al. 2004) have approximately similar rank sum. It should be noted that the mosses concerned have different accumulation capacities in relation to the various 
elements. When concentration values of elements are compared, it becomes evident that Pleurozium schreberi accumulates $\mathrm{As}, \mathrm{Ba}, \mathrm{Ni}, \mathrm{Hf}, \mathrm{Zn}, \mathrm{Na}$ 1.5-2 times more than Hylocomium splendens and Hylocomium splendens accumulates $\mathrm{Sm}, \mathrm{Mo}, \mathrm{Th}, \mathrm{Hg}$ - 1.5-2 times more than Pleurozium schreberi as well (table 3).

Aulacomnium palustre with ample rhizoid felt along the whole bine has the highest accumulation capacity among paludal mosses. Sphagnum centrale and Sphagnum angustifolium have approximately the same rank sum, because they relate to the same genus and possess similar anatomical-morphological and physiological characteristics (Tyler 1990).

Table 3 contains the average values of element concentrations obtained for two epiphytic mosses (Pylaisia polyantha, Orthotrichum obtusifolium) and the terrestrial moss (Dicranum polysetum) having the highest accumulating abilities. Table 3 shows that epiphytic mosses accumulate and retain elements to a greater extent in comparison to terrestrial mosses. Thus, the advantage of using epiphytic mosses as biomonitors is not only the absence of the influence of soil on the content of elements, which ensures high comparability of the obtained results in different areas, but also in their high accumulation capacity compared to terrestrial mosses. Besides, the use of epiphytic mosses enables analysis of atmospheric pollution in industrial centers and inhabited areas. This is practically impossible when terrestrial and paludal mosses are used.

Table 3. Values of concentrations and standard errors in mosses (1-Dicranium polysetum, 2- Ptilium crista-castrensis, 3 -

Hylocomium splendeus, 4- Pleurozium schreberi, 5- Sphagnum central, 6- Sphagnum angustifalium, 7 Sphagnum squarrosum, 8- Aulacomnium palustre, 9- Pylaisia polyantha, 10-Orthotrichum obtusifolium, mg/kg

\begin{tabular}{|c|c|c|c|c|c|c|c|c|}
\hline & $\mathbf{A l} *$ & As & $\mathbf{B a}$ & $\mathbf{B r}$ & Ca & $\mathbf{C d}^{*}$ & Co & $\mathbf{C r}$ \\
\hline 1 & $1620 \pm 167$ & $0.54 \pm 0.04$ & $89 \pm 4$ & $3.2 \pm 0.2$ & $10535 \pm 450$ & $0.45 \pm 0.25$ & $1.3 \pm 0.04$ & $16 \pm 0.7$ \\
\hline 2 & $1350 \pm 344$ & $0.31 \pm 0.034$ & $69 \pm 3$ & $3.3 \pm 0.3$ & $10012 \pm 362$ & $0.33 \pm 0.81$ & $0.98 \pm 0.04$ & $12 \pm 0.5$ \\
\hline 3 & $1340 \pm 55$ & $0.05 \pm 0.004$ & $67 \pm 5$ & $2.7 \pm 0.2$ & $7397 \pm 337$ & $0.31 \pm 0.28$ & $0.79 \pm 0.06$ & $8.4 \pm 0.3$ \\
\hline 4 & $1148.9 \pm 111$ & $0.11 \pm 0.007$ & $89 \pm 11$ & $2.8 \pm 0.2$ & $8068 \pm 559$ & $0.44 \pm 0.28$ & $0.83 \pm 0.04$ & $8.2 \pm 0.4$ \\
\hline 5 & $994 \pm 53$ & $0.04 \pm 0.006$ & $57 \pm 4$ & $3.8 \pm 0.2$ & $5727 \pm 289$ & $0.13 \pm 0.02$ & $0.71 \pm 0.04$ & $11 \pm 1.0$ \\
\hline 6 & $805 \pm 20$ & $0.10 \pm 0.01$ & $107 \pm 7$ & $3.2 \pm 0.2$ & $5560 \pm 253$ & $0.07 \pm 0.01$ & $0.71 \pm 0.03$ & $8.1 \pm 0.4$ \\
\hline 7 & $921 \pm 54$ & $0.13 \pm 0.01$ & $132 \pm 8$ & $3.2 \pm 0.4$ & $9515 \pm 983$ & $0.17 \pm 0.02$ & $0.87 \pm 0.03$ & $11 \pm 1.4$ \\
\hline 8 & $1398 \pm 208$ & $0.61 \pm 0.03$ & $54 \pm 3$ & $3.1 \pm 0.1$ & $7629 \pm 385$ & $0.38 \pm 0.09$ & $1.2 \pm 0.04$ & $9.8 \pm 0.2$ \\
\hline 9 & - & $0.92 \pm 0.12$ & $290 \pm 50$ & $5.2 \pm 0.9$ & $12444 \pm 343$ & - & $2.2 \pm 0.1$ & $92 \pm 5$ \\
\hline \multirow{2}{*}{10} & - & $0.73 \pm 0.03$ & $342 \pm 19$ & $18 \pm 2.0$ & $13660 \pm 1445$ & - & $1.9 \pm 0.2$ & $50 \pm 3$ \\
\hline & Cs & $\mathrm{Cu}^{*}$ & Eu & Fe & Hf & Hg* & La & Mg* \\
\hline 1 & $0.51 \pm 0.02$ & $11 \pm 0.4$ & $0.069 \pm 0.002$ & $2800 \pm 80$ & $0.55 \pm 0.02$ & $0.015 \pm 0.0007$ & $4.7 \pm 0.2$ & $1531 \pm 87$ \\
\hline 2 & $0.29 \pm 0.01$ & $9.7 \pm 1.9$ & $0.05 \pm 0.002$ & $2099 \pm 116$ & $0.21 \pm 0.01$ & $0.03 \pm 0.001$ & $2.2 \pm 0.1$ & $1560 \pm 119$ \\
\hline 3 & $0.27 \pm 0.02$ & $14 \pm 3.2$ & $0.061 \pm 0.003$ & $1730 \pm 83$ & $1.05 \pm 0.06$ & $0.027 \pm 0.001$ & $2.6 \pm 0.1$ & $1327 \pm 63$ \\
\hline 4 & $0.38 \pm 0.02$ & $11 \pm 1.1$ & $0.066 \pm 0.004$ & $2078 \pm 138$ & $0.38 \pm 0.03$ & $0.017 \pm 0.002$ & $2.3 \pm 0.1$ & $1253 \pm 55$ \\
\hline 5 & $0.19 \pm 0.01$ & $7.5 \pm 0.3$ & $0.058 \pm 0.002$ & $1526 \pm 96$ & $0.38 \pm 0.02$ & $0.025 \pm 0.001$ & $2.7 \pm 0.1$ & $1144 \pm 105$ \\
\hline 6 & $0.24 \pm 0.01$ & $5.7 \pm 0.5$ & $0.045 \pm 0.002$ & $1666 \pm 75$ & $0.38 \pm 0.03$ & $0.014 \pm 0.002$ & $2.3 \pm 0.1$ & $1114 \pm 75$ \\
\hline 7 & $0.30 \pm 0.02$ & $6.3 \pm 0.4$ & $0.066 \pm 0.004$ & $1955 \pm 88$ & $0.43 \pm 0.06$ & $0.011 \pm 0.002$ & $2.6 \pm 0.1$ & $2049 \pm 75$ \\
\hline 8 & $0.34 \pm 0.01$ & $9.9 \pm 0.5$ & $0.073 \pm 0.005$ & $2669 \pm 96$ & $0.46 \pm 0.03$ & $0.028 \pm 0.002$ & $4.4 \pm 0.2$ & $1551 \pm 104$ \\
\hline 9 & $0.44 \pm 0.09$ & - & - & $15703 \pm 257$ & - & - & $8.1 \pm 0.3$ & - \\
\hline \multirow[t]{2}{*}{10} & $0.56 \pm 0.08$ & - & - & $5916 \pm 228$ & - & - & $7.1 \pm 0.3$ & - \\
\hline & Mn* & Mo & $\mathbf{N a}$ & Ni* & $\mathbf{P b}^{*}$ & $\mathbf{R b}$ & Sb & Sc \\
\hline 1 & $520 \pm 21$ & $1.6 \pm 0.2$ & $1174 \pm 36$ & $13 \pm 0.7$ & $6.9 \pm 1.6$ & $18 \pm 0.9$ & $0.71 \pm 0.05$ & $0.86 \pm 0.03$ \\
\hline 2 & $509 \pm 52$ & $1.0 \pm 0.1$ & $832 \pm 53$ & $10 \pm 0.6$ & $6.4 \pm 1.3$ & $20 \pm 1$ & $0.48 \pm 0.03$ & $0.62 \pm 0.03$ \\
\hline 3 & $415 \pm 10$ & $1.0 \pm 0.1$ & $229 \pm 14$ & $4.8 \pm 0.3$ & $6.6 \pm 2.2$ & $13 \pm 0.8$ & $0.25 \pm 0.01$ & $0.55 \pm 0.03$ \\
\hline 4 & $448 \pm 2$ & $0.45 \pm 0.05$ & $785 \pm 55$ & $10 \pm 0.9$ & $6.4 \pm 1.4$ & $17 \pm 1.3$ & $0.32 \pm 0.02$ & $0.54 \pm 0.02$ \\
\hline 5 & $290 \pm 6$ & $0.45 \pm 0.03$ & $1104 \pm 75$ & $4.8 \pm 0.2$ & $3.5 \pm 2.0$ & $6.8 \pm 0.4$ & $0.13 \pm 0.01$ & $0.45 \pm 0.02$ \\
\hline 6 & $390 \pm 33$ & $1.7 \pm 0.1$ & $474 \pm 29$ & $3.9 \pm 0.4$ & $1.4 \pm 0.5$ & $10 \pm 1.1$ & $0.31 \pm 0.02$ & $0.49 \pm 0.02$ \\
\hline 7 & $504 \pm 20$ & $1.0 \pm 0.1$ & $706 \pm 76$ & $9.8 \pm 0.8$ & $3.1 \pm 0.7$ & $15 \pm 1.2$ & $0.16 \pm 0.01$ & $0.58 \pm 0.03$ \\
\hline 8 & $273 \pm 20$ & $1.9 \pm 0.1$ & $996 \pm 46$ & $7.8 \pm 0.4$ & $5.3 \pm 1.9$ & $10 \pm 0.8$ & $0.45 \pm 0.03$ & $0.74 \pm 0.03$ \\
\hline 9 & - & $72 \pm 7.0$ & $3075 \pm 254$ & $59 \pm 3$ & - & $24 \pm 3$ & $1.2 \pm 0.05$ & $1.6 \pm 0.08$ \\
\hline \multirow[t]{2}{*}{10} & - & $4.1 \pm 0.5$ & $2476 \pm 156$ & $85 \pm 5$ & - & $18 \pm 2$ & $0.91 \pm 0.08$ & $1.8 \pm 0.03$ \\
\hline & $\mathbf{S e}^{*}$ & $\mathbf{S i}^{*}$ & Sm & Sr & Th & $\mathbf{T i}^{*}$ & $\mathbf{V}^{*}$ & $\mathbf{Z n}$ \\
\hline 1 & $4.5 \pm 1.3$ & $1271 \pm 85$ & $1.3 \pm 0.05$ & $68 \pm 5$ & $0.98 \pm 0.03$ & $129 \pm 14$ & $3.6 \pm 0.6$ & $55 \pm 2$ \\
\hline 2 & $5.3 \pm 0.7$ & $1154 \pm 178$ & $0.55 \pm 0.02$ & $59 \pm 3$ & $0.59 \pm 0.02$ & $115 \pm 32$ & $2.9 \pm 0.8$ & $56 \pm 2$ \\
\hline 3 & $4.8 \pm 0.7$ & $1166 \pm 100$ & $0.62 \pm 0.06$ & $34 \pm 2$ & $0.74 \pm 0.04$ & $100 \pm 3$ & $3.1 \pm 0.3$ & $38 \pm 2$ \\
\hline 4 & $5.2 \pm 1.1$ & $1046 \pm 144$ & $0.39 \pm 0.03$ & $46 \pm 4$ & $0.54 \pm 0.03$ & $86 \pm 5$ & $2.7 \pm 0.2$ & $51 \pm 3$ \\
\hline 5 & $4.3 \pm 1.0$ & $803 \pm 138$ & $0.64 \pm 0.045$ & $24 \pm 2$ & $0.68 \pm 0.04$ & $72 \pm 4$ & $2.0 \pm 0.3$ & $46 \pm 3$ \\
\hline 6 & $4.0 \pm 1.0$ & $643 \pm 51$ & $0.51 \pm 0.029$ & $29 \pm 3$ & $0.59 \pm 0.04$ & $61 \pm 3$ & $1.7 \pm 0.3$ & $56 \pm 2$ \\
\hline 7 & $4.5 \pm 1.0$ & $925 \pm 113$ & $0.43 \pm 0.038$ & $49 \pm 4$ & $0.65 \pm 0.05$ & $73 \pm 6$ & $1.7 \pm 0.1$ & $126 \pm 3$ \\
\hline 8 & $4.2 \pm 1.4$ & $1552 \pm 167$ & $0.95 \pm 0.056$ & $46 \pm 4$ & $0.95 \pm 0.05$ & $111 \pm 9$ & $3.5 \pm 0.3$ & $67 \pm 4$ \\
\hline 9 & - & - & $2.5 \pm 0.34$ & $145 \pm 12$ & $0.28 \pm 0.03$ & - & - & $307 \pm 14$ \\
\hline 10 & - & - & $2.1 \pm 0.14$ & $167 \pm 11$ & $0.28 \pm 0.02$ & - & - & $542 \pm 17$ \\
\hline
\end{tabular}


In comparison with heavy metal concentrations in some European countries (table 4), it is evident that concentration values of some heavy

Table 4. Heavy metal concentrations (maximum values) mg/kg in Europe 2005/2006 (Harmens et. al. 2008)

\begin{tabular}{|l|l|l|l|l|l|}
\hline \multirow{2}{*}{ Country } & \multicolumn{5}{|c|}{ Element } \\
\cline { 2 - 7 } & $P b$ & $C u$ & $C r$ & $Z n$ & $N i$ \\
\hline Lithuania & 7.67 & 11.6 & 2.28 & 36.7 & 1.98 \\
\hline Latvia & 50.0 & 12.0 & 5.0 & 280.0 & 5.34 \\
\hline Estonia & 3.25 & 7.05 & 1.47 & 24.3 & 1.83 \\
\hline \hline
\end{tabular}

However, it should be stressed that surveys in Europe have been conducted with different species of mosses and with specific methodology (Harmens et. al. 2010 ).

\section{Conclusions}

1. To monitor the atmosphere pollution, one should use one species of moss because different species of mosses (even those belonging to the same systematic groups) have differences in accumulation capacity.

2. Epiphyte moss Pylaisia polyantha is the most wide-spread species and has highest accumulating capacity. Therefore, this moss is regarded as the optimal test-object to monitor the atmospheric pollution. The use of epiphytic mosses enables monitoring of both forest and urbanized areas.

3. It is recommended to use moss species Dicranum polysetum having the highest accumulation capacity for regional monitoring of atmosphere (when terrestrial mosses are used).

\section{References}

Berg T., Steinnes E., Use of moss (Hylocomium Splendens and Pleurozium Schreberi) as biomonitors of heavy metal deposition: from relative to absolute values. Environmental Pollution, 1997, 98 (1), p. 61-71. http://dx.doi.org/10.1016/S0269-7491(97)00103-6

Burton S., Agneta M., Terrestrial and aquatic bryophytes as monitors of environmental contaminants in urban and industrial habitats. Botanical Journal of the Linnean Society, 1990, 104 (1-3), p. 267-280. http://dx.doi.org/10.1111/j.1095-8339.1990.tb02222.x

Chakrabortty S., Paratkar G.T., Biomonitoring of trace element air pollution using mosses. Aerosol and Air Quality Research, 2006, 6 (3), p. 247-258.

Chen Y.E., Yuan S., Su Y.Q., Wang L. Comparison of heavy metal accumulation capacity of some indigenous mosses in Southwest China cities: a case study in Chengdu city. Plant, Soil and Environment, 2012, 56 (2), p. 60-66.

Coskun M., Cayir A., Coskum M., Kilic O., Heavy metal deposition in moss samples from east and south Marmara region, Turkey. Environmental Monitoring and Assessment, 2011, 174 (1-4), p. 219-227. http://dx.doi.org/10.1007/s10661-010-1452-1 metals are about equal. Only the concentration of $\mathrm{Cr}$ was determined higher in Russia than in Europe.
Culicov O., Mocanu R., Frontasyeva M.V., Yurukova L., Steinnes E., Active moss biomonitoring applied to an industrial site in Romania: relative accumulation of 36 elements in moss-bags. Environmental Monitoring and Assessment, 2005, 108 (1-3), p. 229-240. http://dx.doi.org/10.1007/s10661-005-1688-9

Frontasyeva M., Stiennes E., Lyapunov S. M., Smirnov I.L., Biomonitoring of heavy metal deposition in the South Ural region: some preliminary obtained by nuclear and related techniques. Journal of Radioanalytical and Nuclear Chemistry, 2000, 245 (2), p. 415-420. http://dx.doi.org/10.1023/A:1006799513736

Gerdol R., Bragazza L., Marchesini R., Alber R., Bonetti L., Lorenzoni G., Achilli M., Buffoni A., De Marco N., Franchi M., Pison S., Giaquinta S., Palmieri F., Spezzano P. Monitoring of heavy metal deposition in Northern Italy by moss analysis. Environmental Pollution, 2000, 108 (2), p. 201-208. http://dx.doi.org/10.1016/S02697491(99)00189-X

Grgie P., Nadezdin M. Bioaccumulation of heavy metals in mosses. Development of Ecological Perspectives for the 21st Century, Yokohama, 1990, p. 428.

Harmens H., Norris D. and the participants of the moss survey 2008. Spatial and temporal trends in heavy metal accumulation in mosses in Europe (1990-2005). Programme Coordination Centre for the ICP Vegetation, Centre for Ecology \& Hydrology, Bangor, UK

Harmens H. 2010. Monitoring of atmospheric deposition of heavy metals, nitrogen and pops in Europe using bryophytes. ICP Vegetation Coordination Centre. Bangor, $16 \mathrm{p}$.

Manoukian, Edward B. 1986. Mathematical nonparametric statistics. New York: Gordon and Breach Science Publishers, 326 p.

Marinova S., Yurukova L., Frontasyeva M., Steinnes E., Strelkova L., Marinov A., Karadzhinova A. Air pollution studies in Bulgaria using the moss biomonitoring technique. Ecological Chemistry and Engineering S, 2010, 17 (1), p. $37-52$.

Migaszewski Z.M., Gałuszka A., Crock J.G., Lamothe P.J., Dołęgowska S., Interspecies and interregional comparisons of the chemistry of PAHs and trace elements in mosses Hylocomium splendens (Hedw.) B.S.G. and Pleurozium Schreberi (Brid.) Mitt. from Poland and Alaska. Atmospheric Environment, 2009, 43 (7), p. 1464-1473. http://dx.doi.org/10.1016/j.atmosenv.2008.11.035

Onianwa, P.C. Monitoring atmospheric metal pollution: a review of the use mosses as indicators. 
Environmental Monitoring and Assessment, 2001, 71, p. 1350. http://dx.doi.org/10.1023/A:1011660727479

Rühling Å. 1994. Atmospheric heavy metal deposition in Europe - Estimations based on moss analyses. NORD Report 1994:9, Nordic Council of Ministers, Copenhagen, Denmark, 53.

Shotbolt L., Büker P., Ashmore M., Reconstructing temporal trends in heavy metal deposition: Assessing the value of herbarium moss samples. Environmental Pollution, 2007, $147 \quad(1-3), \quad$ p. 120-130. http://dx.doi.org/10.1016/j.envpol.2006.08.031

Steel R. G. D., Torrie J. H. 1980. Principles and Procedures of Statistics. New York: McGraw-Hill Book Co.

Steinnes E. 1989. Biomonitors of air pollution by heavy metals. In Pacyna J. M. and Ottar B. (Eds): Control and fate of atmospheric trace metals. Kluwer Academy Publishers. Dordrecht, 338 p. http://dx.doi.org/10.1007/97894-009-2315-7_15

Steinnes E., Rambaek J. P., Hansen J. E. Large scale multi-element survey of atmospheric deposition using naturally growing moss as biomonitor. Chemosphere, 1992, 25 , p. 735-752. http://dx.doi.org/10.1016/00456535(92)90435-T

Tyler G., Bryophytes and heavy metals: a literature review. Botanical Journal of the Linnean Society, 1990, 104 (1-3), p. 231-253. http://dx.doi.org/10.1111/j.10958339.1990.tb02220.x
Nadezhda K. Ryzhakova - candidate of physical and mathematical sciences, docent in National Research Tomsk Polytechnic University, Department of Applied Physics Engineering.

$\begin{array}{ll}\text { Address: } & \text { Institute of Physics and Technology, } \\ & \text { Tomsk Polytechnic University, } \\ & \text { Tomsk, RF } \\ \text { E-mail: } & n k r @ t p u . r u\end{array}$

Natalya S. Rogova - candidate of engineering sciences, assistant, in National Research Tomsk Polytechnic University, Department of Applied Physics Engineering.

$\begin{array}{ll}\text { Address: } & \begin{array}{l}\text { Institute of Physics and Technology, } \\ \text { Tomsk Polytechnic University, } \\ \end{array} \\ \text { Tomsk, RF } \\ \text { E-mail: } & \text { rogova@interact.phtd.tpu.ru }\end{array}$

Alex L. Borisenko - candidate of biological sciences, docent, in National Research Tomsk State University, Institute of Biology.

Address: Institute of Biology, Tomsk State University, Tomsk, RF

E-mail: $\quad$ alb@sibmail.com 


\title{
Samanų akumuliacinių savybių, naudojamų regioniniams ir vietiniams atmosferos teršalams įvertinti, tyrimas
}

\author{
Nadezhda K. Ryzhakova ${ }^{1}$, Natalia S. Rogova ${ }^{1}$, Alex L. Borisenko ${ }^{2}$ \\ ${ }^{I}$ Fizikos ir technologiju institutas, Tomsko politechnikos universitetas, Tomskas, Rusija \\ ${ }^{2}$ Biologijos institutas, Tomsko valstybinis universitetas, Tomskas, Rusija
}

(gauta 2014 m. spalio mèn., priimtas spaudai 2014 m. rugsëjo mèn.)

\begin{abstract}
Atmosferos sunkiụjų metalų ir kitų toksinių elementų nuosėdų monitoringas, naudojant samanas kaip bioindikatorių, yra plačiai naudojamas visame pasaulyje. Tyrimo tikslas - nustatyti tinkamiausias samanu rūšis pagal jų akumuliacines savybes. Šioje studijoje buvo atliktas sunkiụjų metalų ir kitų toksinių elementu akumuliacijos plačiai paplitusiose viduržemio samanose tyrimas. Tyrimo pagrindinis tikslas buvo ịvertinti 4 skirtingų sausumos samanų rūšių, 4 vandeningų vietovių samanų rūšių bei 2 epifitinių samanų rūšių akumuliacines savybes. Naudojant neutronų aktyvavimo analizę (NAA) ir atomo emisijos spektrometriją (AES) samanu mėginiuose buvo nustatytos 32 elementu koncentracijos. Tyrimas parodè, kad akumuliacinės savybės gali atskleisti reikšmingus skirtumus lyginant tarprūšines ir rūšines savybes. Dicranum polysetum akumuliacinis pajègumas buvo didesnis nei kitų sausumos samanų rūšių, taip pat kaip Aulacomnium palustre didesnis nei kitų vandeningų vietovių samanų. Ši samanos savybẻ buvo panaudota atmosferiniam teršalu monitoringui didžiulejje teritorijoje ypač nustatyti tarpvalstybinę sunkiųjų metalų taršos pernašą. Akumuliacinè epifitinių samanų savybė buvo didesnè nei visų kitų. Epifitinės samanos aptinkamos ant senų medžių žievès (drebulių, tuopų, beržų), dažnai pastebimos miestų teritorijose. Būtent dèl šios priežasties epifitinès samanos gali būti naudojamos ne vien atmosferos teršalu stebėsenai didelèse teritorijose, tačiau ir tiriant atmosferos taršą pramoniniuose rajonuose, taip pat gyvenamosiose vietovèse, norint įvertinti atmosferos užterštumą dèl vietinio taršos šaltinio.
\end{abstract}

